\title{
The model of Integrating Culture and Nation Characters into the School based Curriculum at the Remote Areas in the Border of Indonesia and Malaysia.
}

\author{
(Assessment Development Study based on Curriculum 2013 at the Junior High \\ Schools in the District of Paloh and Sajingan, Sambas, West Borneo Province)
}

\author{
Witarsa \\ FKIP University Tanjugpura \\ Pontianak, INDONESIA
}

\begin{abstract}
The Project Implementation Plan of Tanjungpura University (UNTAN) Pontianak shows an active role in the development of human resources in the border area. UNTAN as Pioneering Center for National Character development, has high integrity in solving of the various problems that occurred in the border region. The aim of this research is describe the model for developing the integration of culture and national characters into school based curriculum in the setting of Curriculum 2013 at the Junior High Schools in Paloh and Sajingan district in Border Region of Indonesia and Malaysia. The Outcomes research are (1) the documents of authentic assessment to be used at Junior High Schools in Paloh, the border Region between Indonesia and Malaysia, (2) Scientific Publications through the national journal accredited by Higher Education. The method used was descriptive qualitative. The data analysis technique used is Discovering Cultural Themes Analysis and focus group discussion (FGD).
\end{abstract}

Keywords: Culture, Character, Assessment, Border Regions

\section{INTRODUCTION}

The problems that are still encountered at the level of primary and secondary education in the districts of Paloh and Sajingan, particularly the problems of teachers in Junior high schools I the District of Paloh and Sajingan are: (1) teachers have different perceptions of the second Core Competence (KI 2) or Social Competence; (2) teachers have different perceptions on how to integrate culture and national character from each Core Competence (KI 2) into each Basic Competence (KD) of all subjects; (3) the teachers are having trouble developing an assessment or evaluation that integrates culture and national character from the second Core Competence (KI 2) into each Basic Competency (KD) of all subjects; (4) the results of interviews with 32 teachers teaching in State Junior High School 1, 2, 3, 4, 5, and 6 in the district of Paloh, show that teachers desperately need guidance to develop make assessments based on culture and nation character nation in the setting of curriculum in 2013.

The important issue related to the assessment based on culture and nation character in curriculum in 2013 for all subjects is the standards for national education do not explicitly mention the nation character and culture be integrated into the standards of national education; whereas, national education standards are very closely related to the development of quality assessment. These mean that first, teachers have not been paying attention to the learning characteristics of each educational unit which is closely linked to the Competency Standards and Content Standards; second, teachers have not paid attention to the standards of graduate competence that provide the conceptual framework of the learning objectives to be achieved. Third, the teachers have not paid attention to the Content Standards as a conceptual framework of learning activities and learning is derived from the level of competence and scope of the material; fourth, the teachers have not paid attention to the standards of graduate competence as the learning target that covers the domains of attitude, knowledge, and skills elaborated for each educational unit; fifth, the teachers have not paid attention to the characteristics of attitude, as one alternative selected from a process of affection which includes receiving, applying, appreciating, understanding, and experiencing, in which all learning activities are oriented to competency-based stages that encourage students to undergo such activity.

This research will produce the assessment documents containing the assessment of the learning process using authentic assessment approach (authentic assessment) that assesses student readiness, processes, and learning outcomes as a whole. The integration of these three assessment components will describe the capacity, style, and acquisition of student learning or even capable of producing instructional effect and nurturing effect of learning.

Authentic assessment results can be used by teachers to plan improvement programs (remedial), enrichment (enrichment), or counseling services. In addition, the authentic assessment results can also be used as materials to improve the learning process in accordance with the Standards of Assessment. Evaluation of the learning process is carried out during the learning process by using the instruments such as questionnaire, observation forms, anecdotal notes, and reflection form.

The research objectives are (1) to establish or personalize indicators of culture and nation characters in accordance with the normative values and, the value of nationalism and cosmopolitan values in the districts of Paloh and Sajingan, Sambas regency, the Border Region of Indonesia and Malaysia Sambas; (2) to integrate 
indicators of culture and nation characters in accordance with the normative values and, the value of nationalism and cosmopolitan values into authentic assessment in the districts of Paloh and Sajingan, Sambas regency, the Border Region of Indonesia and Malaysia.

Curriculum 2013 has mandated the essence of a scientific approach in to learning process. The scientific approach is believed to be the golden bridge for the development of attitudes, skills, and knowledge of the learners. A scientific approach based learning is more effective than traditional learning. The research proves that the teaching and learning process with the traditional approach with the retention of information from the teacher by 10 percent after fifteen minutes will produce the acquisition of contextual understanding by 25 percent. A scientific approach based learning, with the retention of information from the teacher for more than 90 percent after two days, will produce the acquisition of contextual understanding by 50 to 70 percent. The learning process should be guided by the principles of scientific approach. This approach is characterized by protrusion dimension of observation, reasoning, discovery, validation, and an explanation of the truth.

There are many definitions of scientific approach or methods. All of them both have similarities and differences. Wicander and Monroe (2006) in their geology textbook say that "Scientific method - a logical, orderly approach that involves gathering of data, formulating and testing hypotheses, and proposing theories." McMurry and Fay (2008) in their chemistry textbook state that "in scientific method, scientific questions must be asked, and experiments must be carried out to find their answers." The next definition, from a biology text, says that "The classic vision of the scientific method is that observations lead to hypotheses that in turn the make experimentally testable predictions" (Raven, Losos, Mason, Singer, \& Johnson, 2008). Another perspective is from a psychology textbook. This book says that "The scientific method refers to a set of assumptions, attitudes, and procedures that guide researchers in creating questions to investigate, in generating evidence, and drawing conclusions" (Hockenbury \& Hockenbury, 2000). Finally, Ferrante (2008), in his sociology textbook, says that "The scientific method is an approach to the data collection that relies on two assumptions: (1) knowledge about the world is acquired through observation, and (2) the truth of the knowledge is confirmed by verification - that is , by others making the same observations ."

It is clear that the implementation of scientific approach in teaching is perceived similarly in both the natural and social sciences, although one notices slight differences in emphasis as suggested by the vocabulary used in these definitions. The similarity is certainly expected since the social sciences attempt to emulate the systematic approach developed in the physical and natural sciences. Common terminology represents the common jargon that is part of the lexicon of science. Students in the social sciences understand that culture has certain basic components such as language, beliefs, values, and norms. Hence, the lexicon of teaching based on scientific approach can be equated to the linguistic component of the culture of science. The lexicon of teaching based on scientific approach has been adopted not only by the social sciences but also by general education and the public.
There are also some opinions about the nature of assessment. First, Overton (2008) claims that "Assessment is a process of gathering information to monitor progress and make educational decisions if necessary". Second, Palomba and Banta (1999) state that "Assessment is the systematic collection, review, and use of information about educational programs undertaken for the purpose of improving student learning and development." Third, Kizlik (2009) states that "Assessment is a process by which information is obtained relative to some known objective or goal. Assessment is a broad term that includes testing. A test is a special form of assessment. Tests are assessments made under contrived circumstances especially so that they may be administered. In other words, all tests are assessments, but not all assessments are tests." Another definition is proposed by Angelo saying that "Classroom Assessment is a simple method faculty can use to collect feedback, early and often, on how well their students are learning what they are being taught". The last definition is stated by Frey and Alman. (2003). they say that "Evaluation the systematic process of collecting, analyzing, and interpreting information to determine the extent to which pupils are achieving instructional objectives".

The minister of education and culture decree no. No. 65, 2013 (2013: 11) says that "Assessment of learning process is authentic assessment that assesses student readiness, processes, and learning outcomes as a whole. The integration of these three components assessment will describe the capacity, style, and acquisition of student learning or even capability of producing instructional effect and nurturing effect of learning. The results of the authentic assessment can be used by teachers to plan improvement programs (remedial), enrichment (enrichment), or counseling services. In addition, the authentic assessment results can also be used as the materials to improve the learning process in accordance with the Standards of Assessment. Evaluation of the learning process is carried out during the learning process by using the instruments like questionnaire, observation form, anecdotal notes, and reflections.

Based on the above opinion, the evaluation can be defined as a systematic process of collecting, analyzing, up to interpreting data or information obtained through the measurements of learning outcomes in terms of tests and non-test.

\section{RESEARCH METHODS}

The subjects of this research were principals, teachers, and students of public secondary schools of PALSA. The objects of research were the junior high and high schools in the border region of Indonesia and Malaysia, Sambas Regency, especially Junior High Schools in Paloh. In specific, the subjects of research were the formal and informal community leaders who are concerned with the culture and character of the nation in the districts of Paloh and Sajingan. They subsequently became the preliminary informant, key informant, and complementary informants. Purposive sampling technique was used to select the informants. The formal leaders were head of education affairs, head of the district, head of the village, head of the community, head of the neighborhood, teachers, and students. Informal leaders were traditional custom leaders, religious leaders and culture leaders. 
The data were analyzed by using Discovering Cultural Themes Analysis adopted from Bungin (2012). This was done by collecting many themes that focus on culture, cultural ethos, values and symbols of culture, national character, specific characteristics of border people in the domains of culture and characters. The analysis of the theme seeks to discover relationships available in domains that were analyzed, so that it would form an integral and holistic unity in complex patterns that eventually manifest the dominant and less dominant themes or factors.

\section{RESEARCH RESULT}

The following table shows, referring to the indicators, the forms of assessment for each subject.

TABLE I. THE GUIDELINE OF ASSESSMENT FOR INTEGRATING NATION CHARACTERS INTO CURRICULUM 2013

\begin{tabular}{|c|}
\hline Culture and Character \\
\hline $\begin{array}{l}\text { Spiritual Attitude } \\
\text { Appreciate and cherish and appreciate the religious teachings }\end{array}$ \\
\hline Social Attitude \\
\hline $\begin{array}{l}\text { Honest: } \\
\text { trustworthy behavior in words, actions and works }\end{array}$ \\
\hline $\begin{array}{l}\text { Discipline: } \\
\text { The acts that show the orderly conduct and abide the various rules and } \\
\text { regulations }\end{array}$ \\
\hline $\begin{array}{l}\text { Responsible: } \\
\text { Attitudes and behavior of individual to carry out his duties, that he } \\
\text { should do to himself, to the society, to the environment (nature, } \\
\text { society, and culture), and to God. }\end{array}$ \\
\hline $\begin{array}{l}\text { Tolerance: } \\
\text { attitudes and actions that appreciate diversities in ethnic and cultural } \\
\text { background, view, and faith }\end{array}$ \\
\hline $\begin{array}{l}\text { Mutual Cooperation: } \\
\text { working together with others to achieve common goals by sharing } \\
\text { tasks and helping each other rightly }\end{array}$ \\
\hline $\begin{array}{l}\text { Polite: } \\
\text { A good attitude in speaking and behaving. Politeness norms are } \\
\text { relative. It means something that is considered good at a certain place } \\
\text { and time could be different in another place and time. }\end{array}$ \\
\hline $\begin{array}{l}\text { Self Confident: } \\
\text { A mental or psychological condition of a person who gives him/her a } \\
\text { strong belief to do or act. }\end{array}$ \\
\hline
\end{tabular}

Referring to the indicator, then the forms of authentic assessment for culture and nation characters that represents the domains of attitudes (spiritual core competence and social core competence) in the border areas are as follows:

\section{OBSERVATION}

The results is meaningfully imply that the integration culture and nation characters requires an assessment rubric that includes (1) the key indicators of basic competencies whose accomplishment would be assessed, (2) aspects of assessment relevant to the content of the portfolio, (3) perfection load criteria (grade, level) of task results, (4) easy to use by teachers and students, (5) use simple language and easily understood.

\section{DISCUSSION}

The significant implication that we have from the research results is that integrating the culture and nation character into the scientific learning oriented authentic assessment is the instrument of culture and character of the nation into the indicator that allows teachers to implement the Core Competence I and II as important aspects in Curriculum 2013. The learning activities based on a scientific approach to assessment development in schools located in the border of Indonesia and Malaysia must comply with the standard cultural and normative culture of the local community; likewise, the nation characters as the embodiment of normative sociological matters and nation attitude need to be appreciated and developed into all subjects. Based on my observations during the study, there is a misunderstanding about culture and nation characters in teaching and learning processes at schools located in the border areas. Culture and nation characters are not just the responsibility of teachers of Social Sciences, but also the responsibilities of teachers teaching other subjects, such as Mathematics teacher, Natural Sciences teachers and Humanities teachers in teaching knowledge that is inspired by the culture and nation characters. As a result, students later are able to prepare themselves in different situations and competitiveness with neighboring countries.

Referring to the results of research done by Keyes (2010), the limitations of this study is the observation is not yet comprehensive and depth. While the observation is an important cornerstone of authentic assessment in the curriculum 2013 because teachers and students tend to only use textbooks provided by the government. Second, changing the mindset of some of the teachers to always analyze and develop the assessment is quite difficult.

\section{CONCLUSION}

Curriculum 2013 gives the new hope to the teachers to integrate the culture and nation characters into the curriculum in the border region. The border communities in the district of Paloh warmly welcome the integration of culture and nation character due to the increasing need for culture and nation characters institutionalized ranging from houses, schools, local government, Tanjungpura University and the Central Government.

To respond the expectations of principals and teachers in junior high schools in the district of Paloh in the border area between Indonesia and Malaysia border region, focus group discussion (FGD) is done seriously by each subject teacher so that the product of the research is obtained in the form of the Document of Assessment for National Border Curriculum based on curriculum 2013.

\section{REFERENCES}

[1] Angelo, T.A., (1991). Ten easy pieces: Assessing higher learning in four dimensions. In Classroom research: Early lessons from success. New directions in teaching and learning (\#46), Summer, 17-31.

[2] Bungin. Burhan. 2012. Analisis Data Penelitian Kualitatif. Raja Grafindo Persada. Jakarta

[3] Frey, Barbara A., and Susan W. Alman. (2003). Formative Evaluation Through Online Focus Groups, in Developing Faculty to use Technology, David G. Brown (ed.), Anker Publishing Company: Bolton, MA.

[4] Ferrante, J. (2008). Sociology: A Global Perspective. 7th ed. Belmont, CA: Thomson/Wadsworth

[5] Hockenbury, D. H., \& Hockenbury, S. E. (2000). Psychology. 2nd edition. NY: Worth Publishers.

[6] Keyes, Grace (2010) Teaching the Scientific Method in the Social Sciences. The Journal of Effective Teaching, Vol. 10, No. 2, 2010, 18-28 
[7] Kizlik, Bob. (2009). Measurement, Assessment, and Evaluation in Education. Online : http://www.adprima.com/measurement.htm diakses tanggal 20-01-2013.

[8] McMurry, J. E., \& Fay, R. C. (2008). Chemistry. 5th ed. Pearson/Prentice-Hall

[9] Palomba, Catherine A. and Trudy W. Banta. (1999). Assessment essentials: planning, implementing, and improving assessment in higher education. San Francisco, CA: Jossey-Bass Publishers

[10] Permendiknas Nomor 65 Tahun 2013 tentang Standar Penilaian. Jakarta: Kemendiknas

[11] Raven, P. H., Losos, J.B., Mason, K.A., Singer, S.R., \& Johnson, G.B. (2008). Biology. 8th ed. New York: McGraw-Hill.

[12] Terry, Overton, (2008). Assessing Learners with Special Needs: An Applied Approach (7th Edition). University of Texas Brownsville

[13] Wicander, R., \& Monroe, J. S. (2006). Essentials of Geology. 4th ed. Thomson Brooks/Cole. 